\title{
СИСТЕМА ОРГАНІВ ЗАБЕЗПЕЧЕННЯ РЕАЛІЗАЦІЇ СУБ'ЄКТИВНИХ ПУБЛІЧНИХ ЕКОЛОГІЧНИХ ПРАВ
}

Постановка проблеми. Згідно зі статтею 3 Конституції України, встановлено пріоритетність здійснення зовнішньополітичних та внутрішньополітичних функцій держави в аспекті забезпечення належного рівня реалізації прав людини, гарантування механізму юридичних та фактичних гарантій захисту прав та інтересів людини. Проголошення людини, іiі життя та здоров'я, честі та гідності, недоторканності та безпеки найвищою соціальною цінністю визначає змістовну характеристику діяльності органів державної влади та місцевого самоврядування [1]. Головним обов'язком функціонування держави $€$ проголошення, забезпечення та захист прав і свобод людини загалом і у сфері охорони навколишнього природного середовища зокрема, реалізація яких сприяє задоволенню не лише приватного інтересу, але й складної сукупності публічних інтересів.

Ступінь наукового розроблення. Визначення складових частин системи органів суб'єктивних публічних екологічних прав $€$ неможливим без характеристики та врахування результатів наукових розробок таких учених, як П.М. Рабінович, А.М. Колодій, О.Ф. Фрицький, В.А. Січевлюк І.О. Ієрусалімова, О.В. Петришин, а також інших представників науки загальної теорії держава та права, науки конституційного права. Окремі аспекти реалізації та захисту суб'єктивних публічних прав вирішувалися в межах галузевих досліджень, здійснених, зокрема, такими вченими, як Т.О. Мацелик, В.К. Колпаков, Т.О. Коломоєць, Ю.О. Легеза, О.Ю. Синявська. Однак комплексного дослідження суб'єктивних публічних екологічних прав, визначення їх місця у системі прав людини досі не було здійснено.

Метою статті є дослідження системи органів суб'єктивних публічних екологічних прав.

Виклад основного матеріалу. До системи суб'єктивних публічних екологічних прав належать право на вільний доступ до інформації про стан довкілля; право об'єднуватись у громадські природоохоронні формування; право одержання екологічної освіти; право брати участь у розробленні та прийнятті управлінських рішень з питань використання природних ресурсів та природних об'єктів. Реалізація суб'єктивних публічних екологічних прав передусім пов'язується з функціонуванням органів публічного управління. Загальнотеоретичний підхід до визначення сутності системи публічного управління у сфері реалізації та захисту конституційних прав людини базується на багатовекторності іï функціонування. Здійснення функцій публічного управління передбачає, як зазначає Н.О. Обушна, поєднання складної сукупності суб'єктів у політичній, екологічній, економічній, соціальній, адміністративній, правовій, гуманітарній сферах тощо. При цьому вченою наголошується на тому, що ефективність здійснення функцій публічного управління обумовлюється впливом як внутрішніх (нестабільність 
соціально-політичної системи держави, триваюча економічна криза), так і зовнішніх факторів (геополітичного середовища, світових фінансових кризових явищ тощо). Такий підхід відзначає необхідність дослідження системи суб'єктів публічного управління у їх співвідношенні з політикою, економікою, правом та іншими суспільними процесами та явищами [2, с. 54].

T.B. Іванова обгрунтовує авторський підхід до розуміння сутності систем суб'єктів управління у сфері використання природних ресурсів як системи органів державної влади та органів місцевого самоврядування, функціонування яких переслідує мету реалізації законодавства, контролю за дотриманням вимог екологічної безпеки, забезпечення вжиття ефективних і комплексних заходів щодо охорони навколишнього природного середовища, раціонального використання природних ресурсів, досягнення узгодженості дій державних і громадських органів під час вжиття екологічних заходів [3]. В межах докторської дисертації Ю.О. Легези обгрунтовується доцільність у межах системи публічного управління у сфері використання природних ресурсів виокремлення органів загальної компетенції та органів спеціальної галузевої компетенції [4, с. 97-99]. Відзначається, що метою функціонування органів загальної компетенції у сфері охорони довкілля $є$ реалізація правотворчої функції держави, що полягає у розробленні та прийнятті нормативно-правових актів загальної діiі, впровадження положень яких дає змогу забезпечити систему гарантій прав та свобод людини. Органи загальної компетенції у сфері публічного управління встановлюють засади реалізації державної політики у сфері екологічної безпеки держави. Органи спеціальної галузевої компетенції державної влади є уповноваженими на реалізацію загальнонаціональної політики у сфері охорони навколишнього природного середовища [5, с. 98]. При цьому реалізація спеціальної галузевої компетенції та віднесення органів державної влади та місцевого самоврядування до такої гілки системи публічного управління передбачають здійснення організаційної діяльності суб'єктів адміністративно-правового регулювання, що не виходить за межі їх компетенції, а їх головне завдання полягає у безпосередньому забезпеченні потреб суспільства у наданні відповідної категорії публічних послуг [6, с. 27-33]. Такий підхід до виділення органів загальної та спеціальної компетенції системи публічного управління може бути доповнено виокремленням органів міжгалузевої компетенції, що виконують функції для всіх або більшості галузей і сфер суспільно-державного життя [7, с. 82].

До суб'єктів загальної компетенціï у сфері суб'єктивних публічних екологічних прав належать Верховна Рада України як єдиний законодавчий орган; Президент України як глава держави; Кабінет Міністрів України як вищий орган виконавчої влади; місцеві державі адміністрації як органи регіонального управління. Міжгалузевою компетенцією у сфері забезпечення реалізації суб'єктивних публічних екологічних прав людини наділені такі органи державної влади, як Міністерство внутрішніх справ України, Генеральна прокуратура України, Служба Безпеки України, Рада національної безпеки та охорони України, Міністерство розвитку економіки, торгівлі та сільського господарства України, Міністерство закордонних справ України, Державна судова адміністрація України. Органи міжгалузевої компетенції у сфері забезпечення суб'єктивних публічних екологічних прав людини полягають у сприянні реалізації адміністративних дозвільно-ліцензійного провадження, контрольно-наглядових, інформаційних проваджень. Особливе значення у системі забезпечення суб'єктивних публічних екологічних прав мають Центри надання адміністративних 
послуг України. Так, відповідно до статті 9 Закону України «Про адміністративні послуги», визначено, що досягнення результату здійснення владних повноважень за ініціативною заявою фізичної або юридичної особи, спрямованої на набуття, зміну чи припинення прав та/або обов'язків заявника, є можливим у формі реалізації функціонування органу публічного управління чи через так званого посередника, яким $є$ центр надання адміністративних послуг [8]. Регулювання функціональної компетенції таких суб'єктів публічного управління здійснюється безпосередньо положеннями Постанови Кабінету Міністрів Украіни «Про затвердження Примірного положення про центр надання адміністративних послуг» від 20 лютого 2013 р. № 118 [9]. Завдання функціонування центрів з надання адміністративних послуг полягають у здійсненні «організації надання адміністративних послуг у найкоротший строк та за мінімальної кількості відвідувань суб'єктів звернень; спрощення процедури отримання адміністративних послуг та поліпшення якості їх надання; забезпечення інформування суб'єктів звернень про вимоги та порядок надання адміністративних послуг, що надаються через адміністратора» [10]. Як зазначає Є.О. Легеза, створення ЦНАП сприяє зменшенню проявів корупційних ризиків за рахунок усунення особистого контакту суб'єкта звернення 3 представником органу влади, відповідального за надання послуги [11, с. 137-138].

До органів публічного управління спеціальної компетенції у сфері реалізації та забезпечення суб'єктивних публічних екологічних прав необхідно віднести Міністерство захисту довкілля та природних ресурсів України та його територіальні управління [12], Державну служба 3 питань геодезіі, картографіï та земельного кадастру [13], Державне агентство рибного господарства України [14], Державне агентство водних ресурсів
України [15] та інші органи державної влади та їх територіальні управління. До системи суб'єктів, уповноважених на забезпечення реалізації та захисту суб'єктивних публічних екологічних прав, необхідно віднести громадські об'єднання, юридичних осіб приватного та публічного права. Зокрема, відповідно до чинного законодавства України, реалізація особою права на доступ до публічної екологічної інформаціі пов'язується 3 функціонуванням не лише органів державної влади та місцевого самоврядування, але й інших суб'єктів, які виконують функції розпорядника екологічної інформації. Так, відповідно до Закону України «Про доступ до публічної інформації [16], визначено, що розпорядником екологічної інформації є, зокрема, «суб'єкти господарювання, які володіють: 1) інформацією про стан довкілля; 2) інформацією про якість харчових продуктів і предметів побуту; 3) інформацією про аварії, катастрофи, небезпечні природні явища та інші надзвичайні події, що сталися або можуть статися і загрожують здоров'ю та безпеці громадян; 4) іншою інформацією, що становить суспільний інтерес (суспільно необхідною інформацією)» (частина 2 статті 13).

В межах дослідження до системи органів загальної та міжгалузевої компетенціі, уповноважених на забезпечення реалізації суб'єктивних публічних екологічних прав, віднесено Верховну Раду України. Тривають дискусії щодо віднесення до складових частин системи публічного управління єдиного законодавчого органу. В цьому аспекті варто виділити позицію Р.С. Мельника, що обгрунтовує, що до системи суб'єктів публічного управління необхідно віднести Верховну Раду України (зокрема, в особі ii апарату, що є уповноваженим на здійснення інформаційних проваджень), органи судової влади (зокрема, апарату суду, що $є$ уповноваженим на надання громадянину 
можливості ознайомитися із судовим рішенням на підставі Закону України «Про доступ до судових рішень» [17]). Варто відзначити, що, відповідно до статті 13 Закону України «Про охорону навколишнього середовища» від 25 червня 1991 р. [18], до виключної компетенції Верховної Ради України належить визначення основних напрямів державної політики у галузі охорони навколишнього природного середовища; прийняття та затвердження загальнодержавних екологічних програм; затвердження указів Президента України про оголошення окремих місцевостей зонами надзвичайної екологічної ситуації; вирішення інших питань у галузі охорони навколишнього природного середовища відповідно до Конституції України

Реалізація суб'єктивних публічних екологічних прав людини пов'язується 3 діяльністю Президента України, до компетенції якого належить не лише здійснення функцій із репрезентації держави на рівні міжнародної світової спільноти (в цьому аспекті варто відзначити, що за ініціативою глави української держави було порушено подання позову проти Російської Федерації до міжнародного арбітражу, предметом оскарження в якому є права держави, задекларовані у Конвенції ООН з морського права 1982 р. [17]), але й розгляд звернення громадян із необхідністю відповідного реагування на заяву чи скарги [18].

Діяльність Кабінету Міністрів України спрямована на реалізацію суб'єктивних публічних екологічних прав у формі здійснення таких повноважень, як розроблення та впровадження державної та регіональної екологічної політики, зокрема шляхом ухвалення та виконання державних загальнонаціональних, міждержавних i регіональних екологічних програм; координація діяльності міністерств, відомств, інших установ та організацій України в питаннях охорони навколишнього природного середовища [19]. Державні адміністрації в областях і районах, містах Києві і Севастополі $€$ місцевими органами виконавчої влади та забезпечують виконання регіональних програм охорони довкілля, взаємодію з органами місцевого самоврядування, реалізацію делегованих відповідними радами повноважень [20].

Органи міжгалузевої компетенції виконують свої повноваження у сферах суспільного життя, що $є$ суміжними з охороною навколишнього природного середовища [21].

Однак пріоритетне значення у системі органів, функціонування яких сприяє забезпеченню реалізації суб'єктивних публічних екологічних прав, відводиться органам спеціальної (галузевої) компетенції, серед яких центральне місце посідає Міністерство захисту довкілля та природних ресурсів України, а також його територіальні управління [10]. Саме Міністерство захисту довкілля та природних ресурсів України та його територіальні управління реалізують державну політику у сфері охорони навколишнього середовища та раціонального використання природних ресурсів, формування національної екологічної мережі, здійснюють державний контроль відповідно до екологічного законодавства в Україні, управління охороною Й використанням територій та об'єктів природно-заповідного фонду України, готують пропозиції щодо удосконалення природокористування та запобігання забрудненню навколишнього середовища, здійснюють міжнародне співробітництво та залучення міжнародної технічної допомоги у сферу заповідної справи [10]. Міністерство захисту довкілля та природних ресурсів України «проводить моніторинг та оцінювання результатів реалізації державної політики з питань, що належать до його компетенції, та розробляє на основі такого оцінювання пропозиції щодо iï продовження, коригування чи припинення; координує діяльність центральних та місцевих органів 
виконавчої влади з питань, що належать до його компетенції; здійснює розгляд звернень громадян з питань, пов'язаних 3 його діяльністю, підприємств, установ та організацій, що належать до сфери його управління; бере участь у здійсненні заходів щодо адаптації законодавства України до законодавства ЄС» (пункти 12, 13, 15 Постанови КМУ від 25 червня 2020 p. № 614) [10].

Висновки. Таким чином, до системи органів у сфері реалізації та захисту суб'єктивних публічних екологічних прав належать органи загальної, спеціальної та міжгалузевої компетенції. Центральним органом державної влади у сфері суб'єктивних публічних екологічних прав $є$ Міністерство захисту довкілля та природних ресурсів Украіни як центральному органу виконавчої влади, а також його територіальні управління на регіональному рівні.

У науковій статті здійснено характеристику системи органів суб'єктивних публічних екологічних прав. Метою статmі є дослідження системи органів суб'єктивних публічних екологічних прав. Підкреслено, що реалізація суб'єктивного публічного права $\epsilon$ неможливою без вчинення суб'єктом владних повноважень певних дій, певного обов'язку, реалізація якого має відбуватися в межах управлінської діяльності в активній формі. До системи суб'єктивних публінних прав віднесено право особи на власні діï; право особи вимагати від суб'єкта владних повноважень вчинення певних дій; право приватної особи вимагати надання публічних (зокрема, адміністративних) послуг; право на оскарження дій, бездіяльності та iï результатів органів публічної адміністрації. Аргументовано, що об’єктивізація публічного екологічного інтересу пов'язується з його виникненням до моменту набуття повної правосуб'єктності учасни- ком правовідносин та усвідомлення ним соціальної значущості ефективності його реалізації. Обгрунтовано доцільність розуміння під суб’єктивним публічним екологічним правом приватної особи визначену чинним законодавством можливість участі приватної особи у реалізаціі природоохоронної (екологічної) функції держави. Визначено, що змістом суб'єктивного публічного екологічного права $\epsilon$ задоволення соціального інтересу у запобіганні виникненню надзвичайних екологічних ситуацій, забезпеченні раціонального використання природних ресурсів загальнодернавного та місцевого значення, що своїм результатом має зростання рівня якості життя та здоров'я людини. Встановлено, що видами суб'єктивних публічних екологічних прав є право на вільний доступ до інформації про стан довкілля, право об'єднуватись у громадські природоохоронні формування, право одержання екологічної освіти тошо, а до системи органів у сфері реалізації та захисту суб'єктивних публічних екологічних прав належать органи загальної, спеціальної та міжгалузевої компетениії. Центральним органом державної влади у сфері суб'єктивних публічних екологічних прав є Міністерство захисту довкілля та природних ресурсів України як центтральнии орган виконавчої влади, а також його територіальні управління на регіональному рівні.

Ключові слова: громадянин, людина, механізм, обов'язки, правовий статус, суб'єктивне публічне право, суб'єктивне публічне екологічне право.

Barlit A. System of bodies ensuring the implementation of subjective public environmental rights

The scientific article describes the system of subjective public environmental rights. The purpose of 
the study of the system of subjective public environmental rights. It is emphasized that the implementation of subjective public law is impossible without the subject of power of certain actions, a certain duty, the implementation of which must take place within the management activities in an active form. The system of subjective public rights includes: the right of a person to his own actions; the right of a person to demand from the subject of power to perform certain actions; the right of an individual to demand the provision of public (including administrative) services; the right to appeal against actions, inaction and its results of public administration bodies. It is argued that the objectification of the public environmental interest is associated with its emergence until the acquisition of full legal personality by the party to the legal relationship, and his awareness of the social significance of the effectiveness of its implementation. The expediency of understanding the subjective public environmental law of an individual is substantiated. It is determined that the content of subjective public environmental law is to satisfy the social interest in preventing environmental emergencies, ensuring the rational use of natural resources of national and local importance, which results in an increase in quality of life and human health. It is established that the types of subjective public environmental rights are the right to free access to information about the state of the environment, and the right to unite in public environmental groups, and receive environmental education, etc. to the system of bodies in the field of implementation and protection of subjective public environmental rights include bodies of general, special and intersectoral competence. The central body of state power in the field of subjective public environmental rights is the Ministry of Environmental Protection and Natural Resources of Ukraine as the central body of executive power, as well as its territorial departments at the regional level.

Key words: citizen, person, mechanism, responsibilities, legal status, subjective public law, subjective public environmental law.

\section{Література}

1. Конституція України від 28 червня 1996 р. Відомості Верховної Ради України. 1996. № 30. Ст. 141.

2. Обушна Н.О. Публічне управління як нова модель організації державного управління в Україні: теоретичний аспект. Ефективність державного управління. 2015. Bun. 44. С. 53-63.

3. Іванова Т.В. Механізм управління природокористуванням $i$ екологічною безпекою. URL: http: / / wrw.nbuv.gov.ua / portal/Soc_ Gum/Nvamu_upravl/2011_1/13.pdf.

4. Легеза Ю.О. Адміністративно-правові засади публічного управління у сфері використання природних ресурсів : дис. ... докт. юрид. наук : спец. 12.00.07 ; ЗНУ. Запоріжжя, 2018. 512 c.

5. Кордун О.О. Особливості виконавчої влади в пострадянській Україні : монографія. Київ : МАУП, 2000. 248 с.

6. Адміністративне право України. Повнии курс : підручник. Херсон ОЛДІ-ПЛЮС, 2018. 446 с.

7. Про адміністративні послуги : Закон України від 6 вересня 2012 р. № 5203VI. Відомості Верховної Ради. 2013. № $32 . \mathrm{Cm}$. 409 .

8. Про затвердження Примірного положення про центр надання адміністративних послуг : Постанова Кабінету Міністрів України від 20 лютого 2013 р. № 118. Офіційний вісник України. 2013. № 16. Cm. 557.

9. Легеза Є.О. Теорія публічних послуг: адміністративно-правова складова : монографія. Херсон : Видавничии дім «Гельветика», 2016. 452 с.

10. Деякі питання Міністерства захисту довкілля та природних ресурсів : Постанова Кабінету Міністрів України від 25 червня 2020 p. № 614. Офіційний вісник України. 2020. № 59. Ст. 1853.

11. Про Державну службу України з питань геодезіі, картографіі та када- 


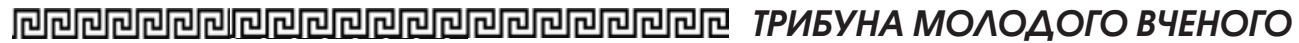

стру : Постанова Кабінету Міністрів України від 14 січня 2015 р. № 15. Офіційний вісник України. 2015. № 7. Ст. 164.

12. Про затвердження Положення про Державне агентство рибного господарства України : Постанова Кабінету Міністрів України від 30 вересня 2015 р. № 895. URL: https: / / zakon.rada.gov.ua/ laws/show/895-2015-n\#Text.

13. Про затвердження Положення про Державне агентство водних ресурсів України : Постанова Кабінету Міністрів України від 20 серпня 2014 р. № 393. URL: https: / / zakon.rada.gov.ua/laws / show / 393-2014-n\#Text.

14. Про доступ до публічної інформаціі : Закон України від 13 січня 2011 р. № 2939-VI. Відомості Верховної Ради України. 2011. № 32. Сm. 314.

15. Про доступ до судових рішень : Закон України від 22 грудня 2005 р. № 3262-IV. Відомості Верховної Ради України. 2006. № 15. Cm. 128.

16. Про охорону навколишнього природного середовища : Закон України від 25 червня 1991 р. (зі змінами $i$ доп.).
Відомості Верховної Ради України. 1991. № 41. Cm. 546 .

17. Конвенція ООН з морського права 1982 р. : ратиф. Україною 3 червня 1999 р. Законодавство України. URL: http:// zakon2.rada.gov.ua/laws/show/995_057.

18. Про звернення громадян : Закон України від 2 жовтня 1996 р. № 393/96ВР. Відомості Верховної Ради України. 1996. № 47. Cm. 256.

19. Про Кабінет Міністрів України : Закон України від 27 лютого 2014 р. № 794-VII. Законодавство України. URL: http: / / zakon3.rada.gov.ua/laws / show/794-18.

20. Про місцеві державні адміністраиії : Закон України від 9 квітня 1999 р. № 586-XIV. Відомості Верховної Ради України. 1999. № 20-21. Ст. 19.

21. Питання Міністерства розвитку економіки, торгівлі та сільського господарства: Постанова Кабінету Міністрів України від 20 серпня 2014 р. № 459. URL: https: / / zakon.rada.gov.ua/laws / show /459-2014-n\#Text. 